\title{
West African International Studies: Approaches to Regional Security
}

\author{
A.Yu. Shipilov \\ Institute of World History, Russian Academy of Sciences, Moscow, Russian Federation
}

\begin{abstract}
This article covers the most significant theoretical schools in West Africa in the framework of the international relations analysis, with special focus on the regional security. Major respective theoretical approaches to the given issues are assessed based on the writings of local experts that frequently reevaluate the major articles of faith connected with neo-Realist, neo-Liberal and Marxist views.

Particular attention is drawn to the examination of various interpretations of the role that belongs to supranational regional structures in West African conflict resolution using the case of the Liberian civil war. The most crucial part of the research presented is an analysis of publications issued by Adekye Adebajo and Ismail Rashid, two leading West African specialists in the field of regional security. Their appraisal of collective security mechanisms' perspectives in the most poverty-stricken and unstable regions of the world is elaborated upon.

The aim of the article is to determine the extent of uniqueness present in Adebajo and Rashid's approaches compared to their Western and African colleagues but also to figure how West African 1990-2000's conflicts' analysis did have an impact on the scholars' theoretical views and more broadly what was its contribution to the regional understanding of international relations.

The research is based upon comparative and historical-genetic methods as well as case studies. The major elements composing the scholars' analysis of successes and failures in the path of West African integration are presented along with their appraisal of the ECOWAS security component. A comparison is made between their views and those of their regional colleagues belonging to other schools of thought as well as Western theories that had the greatest impact on these authors.
\end{abstract}

Key words: West Africa, regional integration, Liberia, International Relations, collective security, English school

Decolonization of the vast majority of Asian and African countries in the middle of the XXth century and a drastic increase in the number of independent states caused a situation when the system of international relations became less Western-centric. The newly independent nations joined the UN system, fit into the bipolar world order, developed relations with their former colonial overlords and their neighbors in multiple ways. Having previously been almost fully colonized, Africa was also actively engaged in these processes. The most intense emergence of subregional intergovernmental political structures and more advanced partnership and rivalry dynamics were seen in West Africa which has experienced the establishment of a regional relations subsystem in the wake of war in the south-east of Nigeria in 1967-1979. Moreover, the fact that West Africa has seen 41 out of 75 military coups that took place on the continent signifies the importance of integration and collective security mechanisms emergence. Later, the set-up of a relatively successful regional integration platform (the Economic Community of West African States - ECOWAS) became the premise for the development of local International Relations theorists elaborating primarily on the regional context.

\section{Emergence of West Africa's Major IR Theoretical Schools}

Starting from 1960s West African IR approaches emerged in the framework of several major schools. Economic difficulties and development problems faced by African countries upon dismantling the formal colonial system led to the establishment of the dependence theory school built on Marxist and neoMarxist understanding of historical processes. Samir Amin residing in Senegal became the most prominent representative of this approach in West Africa, having criticized the de-facto prevailing economic dependence of African states on their former colonial powers [Amin 1968; 1972].

Later this tradition was continued throughout the publications of Amos Sawyer, a Liberian scholar and left-wing opposition political activist, similarly critical of the external exploitation of African states through the assistance of the local elites [Sawyer 
2004]. The ranks of the West African neo-Marxist international relations commentators also include Thomas Sankara, Burkinabe president in 1983-1987, considering his anti-dependence political agenda and an overarching goal of drawing West Africa away from the periphery of the global capitalist system [Sankara 1988]. This approach maintained its popularity even in the wake of the Cold War.

Similar views were expressed by the more nationalist segments of West African political thought. Among others, Laurent Gbagbo (Ivorian scholar and politician turned president in 2000), accompanied by his followers, spoke of de-facto control of the regional economies by the former colonial overlords [Gbagbo 1983; Koulibaly 2007]. Institutional development and Pan-African unity in the face of external influences were put forward as solutions to the continent's fundamental challenges by Kwame Nkrumah, Ghana's first president (also occupied in the field of social sciences prior to entering politics) [Nkrumah 1967].

Apart from that West Africa has seen the development of regional IR schools more closely tied to the more mainstream Western approaches in the field. Neo-Liberal institutionalism principles, having gained popularity in the 1990s due to Robert Koehane and Joseph Nye's works [Keohane, Nye 2001], became crucial for researchers grouped around the Kofi Annan International Peacekeeping Training Center situated in Ghana ${ }^{1}$. These researches share the assumption that interregional cooperation is a key to solving intergovernmental and internal problems relevant for West Africa. Nevertheless, the Center faculty members including Kwesi Aning and Kwaku Osei-Hwedi, follow their Western counterparts in drawing their attention mostly toward the peacekeeping capacities of the large international organizations and separate actors and insufficiently covering West African mechanisms of collective security [Aning, Salihu 2011; Boateng, Osei-Hwedie 2017].

The ranks of the more prominent local researchers of West African political processes (previously studied mostly by Europeans) of the last decade with a more unique African perspective include Adekeye Adebajo and Ismail Rashid, professing more moderate research assumptions than those of the Kofi

1 Kofi Annan International Peacekeeping Training Centre (KAIPTC). URL: https://www.kaiptc.org (accessed: 19.12.2018).
Annan Center. Their analysis of regional processes is largely based on the Western academic tradition. Both Nigerian - Adekeye Adebajo and Sierra Leonean Ismail Rashid have at least partially received their formal education in the Anglo-Saxon world. The former one received Rhodes scholarship and was thus able to attend Cambridge University ${ }^{2}$. The later has been academically engaged in Canada for a great while, having received a PhD in McGill University. Therefore the more moderate views with respect to the effectiveness and content of the trans-border conflict resolution mechanisms posed by these authors can be explained by the familiarity with the principles put forward by the British school of International Relations studies (namely by Hedley Bull) [Bull 1977; Watson 2009].

The aforementioned school takes a middle position regarding the argument of neo-Realists and Liberal institutionalists on the possibility of equal multi-party cooperation in conflict prevention and resolution. Overall the representatives of this approach recognize the viability of both rigid the hegemonic model of intergovernmental ties based on power (based on the realist presumptions) and mutually beneficial peaceful cohabitation and cooperation (dominant in the neo-liberal worldview) depending on the level of development and conditions of relations between specific countries [Bull 1977: 151]. It is this pluralism in assessing particular forms and methods of international relations practice that was employed by the two West African scholars [Adebajo, Rashid 2004].

They address the empiric material by setting the research question of whether the hegemonic structure of the intergovernmental relations dominates on the regional level or the supranational institutions play a more significant role. Their main focus is on the conflicts that shattered West Africa in 1989-2004 (mainly civil wars in Liberia and Sierra Leone) as well as the response generated by the subregional integration structures.

The aim of given article is to determine the extent of the uniqueness of the approach practiced by Adebajo and Rashid in comparison with their Western and African colleagues (namely from the Kofi Annan Center) with respect to the issues of re-

2 He serves as the executive director at Centre for Conflict Resolution in Cape Town. 
gional security, and also to assess the $1990-2000$ s West African civil wars analysis influence on the development of the authors' theoretical views and West African understanding of International Relations in general. Qualitative, largely hermeneutic, historiographical and comparative methodological approaches are used to study this. Particular methods applied include comparative and historicalgenetic methods as well as case studies.

Their substantive views are studied primarily through their joint book, "West Africa's Security Challenges: Building Peace in a Troubled Region" published in 2004 immediately after the end of the two wars [Adebajo, Rashid 2004]. However other publications by the same authors devoted to the same set of problems are also considered, namely Adekeye Adebajo's "Building Peace in West Africa: Liberia, Sierra Leone and Guinea Bissau' published in 2002 [Adebajo 2002].

\section{Appraisal on Intraregional Tensions as Premises for the Emergence on Integration Institutions}

The authors begin their analysis of the state the West African collective security institutions by exploring the historical premises for the development of the subregional integration framework, believing them to be the roots of the situation existent in the 1990s. Adebajo and Rashid largely link their emergence to the structure of colonial governance in the region, the proximity of countries with common colonial past and similar patterns of decolonization. Namely they note the extreme importance of West Africa's split into French and British colonies at the turn of the 20th century (apart from several minor coastal territories controlled by other powers, Cape Verde and Guinea Bissau under the Portuguese rule, German colonies in Togo and Cameroon as well as nominally independent Liberia built by freed slaves under strong American influence) [Adebajo, Rashid 2004: 22].

According to Adebajo and Rashid, the emergence of supranational mechanisms in West Africa was heavily impacted by the colonial legacy of the respective European powers, each managing its various African colonies in a relatively single fashion. As a result every group of former colonies had roughly similar legal and monetary system, judiciary and law protection mechanisms all contributing to stark similarities inside the given group of countries [Mensa 2014: 245-246]. Thus the two researchers split the region into two major parts, former French and British colonies. However they also hold that the differences between these two groups of countries have created serious tensions among West African states later on, after gaining independence. Their views are that these two groups of former colonies have both generated the first regional integration drivers and internal strife in this integration framework. Therefore Adebajo and Rashid look into the peculiarities of French and British colonial policies on these territories, considering them fateful for regional integration projects [Adebajo, Rashid 2004: 27].

The two authors see the major difference between French and British colonial policy in West Africa in the use of direct or indirect rule. The French colonialism is noted to have been aimed at long-term assimilation of the local population by spreading French education and drawing the governed into the French culture, providing Africans with full rights of French citizens in case of their complete assimilation [Searing 2005: 1334-1335]. Parallel statehood forms were also developed in the form of association rather then turning the governed into the "black French". The majority of the indigenous population was fully disenfranchised until 1946 and could be used in mandatory public works or become subject to minor extrajudicial punishment. Nevertheless the residents of the French colonies were much more exposed to European cultural influence than other Africans during the colonial era [Ginio 2006: 3 - 4]. Hierarchical direct rule system was necessary in order to create proper conditions for assimilation. Traditional authorities, even if preserved, were stripped of substantial power by the colonial bureaucracy as self-governance and isolation of any territory based on traditional principles threatened the assimilation policy. Therefore the French colonial policy in Adebajo and Rashid's writings appears to be mainly based on direct rule.

This system of colonial governance, according to the two authors, became the foundation for a more sustainable regional integration pattern specifically for the Francophone West African countries. African elites with French education and middle-rank positions in the colonial administration became closely tied to France which had a crucial impact on their policies after independence. In 1958 French West 
African colonies reemerged into 8 overseas territories (apart from Togo) governed by these same elites. France voluntarily offered independence to its West African territories after the crises in Vietnam and Algeria and thus was able to maintain some of its privileges in the region. Based on this "Françafrique" was built on informal elite ties, common currency and a system of French military bases [Adebajo, Rashid 2004: 34]. The two researchers explain the longevity of these close relations and further intensified integration among the Francophone West African states by these features of the French colonial policy [Adebajo, Rashid 2004: 32].

To the contrary, they view the British colonial system to have been favoring indirect form of governing the new territories through interaction with precolonial authorities. Adebajo and Rashid hold that the most finite example of such approach can be seen in British colonization of the North Nigerian Muslim Emirates and Sultanates. The theoretical framework for it was drawn by the works of Frederic Lugard, the British practitioner ad theoretician of colonial governance [Lugard 1922]. This territory had the most developed pre-colonial statehood in West Africa, as was believed, which made direct rule less necessary if not costly in terms of military presence. West African climate was considered to be unsuitable for Europeans which excluded serious settler movement. Sahel Muslim states had the umbrella power structure where local authorities recognized the divine superiority of the Sultan without practically obeying him. Therefore the conditions of colonial governance here drastically differed from those on the French-controlled territories [Adebajo, Rashid 2004: 33].

British administration chose to support the traditional elite in hope of maintaining status quo in West African societies providing favorable conditions for the operation of British capital. Educated locals were ignored as a potential alternative to traditional elites, being practically absent from the midlevel of colonial administration. African intellectuals' discontent with this situation caused them to actively join the decolonization movement. Adebajo and Rashid deduct that the arrival of these groups into power inevitably caused immediate decline in direct ties between the Great Britain and its former colonies (contrary to the French case in West Africa, where no Commonwealth parallel had emerged but instead there was a set of specific integration mechanisms). This explanation is used by the two authors to understand why the new elite preferred the ideas of PanAfricanism that emerged in the 19th century outside Africa in the US and West Indies [Adebajo, Rashid 2004: 33]. Adebajo and Rashid posit that the efforts of this new elite were instrumental in rapid dismantling of those few integration mechanisms that were left by the British colonial administration to consolidate its former territories (these mechanisms proved weak due to the overall decentralization of authority).

Apart from that, Adebajo and Rashid attach high importance to the fact that the British colonial policies in West Africa resulted in the creation of Nigeria. This country has accumulated inside its current borders a great diversity of ethnic and religious groups, frequently at odds with each other, and became the largest country in the subregion by territory and population with abundant economic resources and military potential. It became the natural pole of regional integration. As West Africa was decolonized in $1950-1960$ s, former overlords left the country with an administrative system capable of enduring the nation's unity despite the economic and political strife that followed independence [Adebajo, Rashid 2004: 36].

It was specifically marked that Nigeria became the self-evident subregional hegemon whose influence was resisted by former colonial powers, mainly France along with its regional allies. The most notable political leaders of Françafrique, Felix Houphouet-Boigny of Ivory Coast and Leopold Sedar Senghor of Senegal, convinced the French establishment to secretly intervene in the Nigerian civil war of 1967-1970 [Wauthier 2002: 2]. Separatists from the Igbo ethnicity residing mainly in the south-east of the country and suffering from streak of military coups and ethnic violence proclaimed an independent Republic of Biafra.

France and its allies hoped to provoke the breakup of Nigeria by assisting the rebels. Adebajo and Rashid suggest that had they succeeded, the balance of power inside West Africa would shift strongly in favor of Francophone countries. Nevertheless, the institutional sustainability and external aid helped Nigeria preserve its territorial integrity despite the odds, and the growth in global oil prices in 1970s (country's major export commodity) made Nigeria's 
regional leadership even more evident [Wauthier 2002: 2]. The emergence of such a powerful player in West African politics is considered by the two researchers to be one of the crucial elements of British legacy [Adebajo, Rashid 2004: 32].

Thus the scholars enrich their analysis of West African integration premises with detailed assessment of regional commonalities and differences originating from the colonial era. The authors evaluate the intraregional tensions based on the subregional entities' previous experience and the build-up of power balance. These roots of West African integration institutional peculiarities are much less addressed by other researchers, including those affiliated with the Kofi Annan Center.

\section{Early Stage of West African Subregional Integration Development}

The breakdown of the colonial system ignited the process of integration in West Africa, leading to the issue of defining sub-regional boundaries. According to Adebajo and Rashid, France's preserved influence and Nigeria's growing strength have made the issue of delineating West Africa's borders increasingly significant for the regional balance of power and the prospects of integration. The two authors indicate that in the early 1970s the negotiation process on the establishment of the West African Economic Union was marked by Leopold Sedar Senghor (closely connected with France despite certain left sympathies) demanding the recognition of West African borders from Cape Verde and Mauritania to Zaire (modern Democratic Republic of Congo) [Adebajo, Rashid 2004: 28]. He believed that Zaire's entry into the region could balance Nigeria as both of these countries, despite the internal problems, maintained a relatively equal potential to contain each other, allowing France and its satellites to play on these differences and strengthen their own regional position. Nevertheless, the Francophone states were not able to push this demand during negotiations and so the integration continued in its current borders (excluding Mauritania).

Adebajo and Rashid describe how newly independent West African states made numerous attempts to forge an intergovernmental regional organization, all unsuccessful due to diverging interests or not sufficiently developed. Reasons for these failures include, according to the researchers, the low trade turnout between the regional states, problems with currency convertibility, language, ethnic or religious differences, lack of sectorial cooperation and external interference. However Nigeria's increased influence helped to overcome these problems [Geveling 2009: 13]. In 1972 Nigeria and Togo came up with joint initiative (communiqué of general Yacoubou Gowon and general Gnassingbe Eyadema during the former's visit to Lome in April 1972), starting the 3-year path towards forging the West African regional organization [Adebajo 2002: 28]. On May, 28 of 1975 the 16 West African states signed an agreement on the establishment of ECOWAS ${ }^{3}$.

The structure and performance mechanisms utilized by the newly emerged organization were designed to attain economic integration, customs and monetary union, fixing basic disproportions between the participant countries and enhancing sustainable growth. Nevertheless the authors note that the political will present in 1972-1975 to promote regional cooperation soon turned into increased skepticism by some of the region's leaders (particularly of the Francophone countries) regarding the effectiveness of ECOWAS. Low intensity of economic integration didn't allow an easy settlement for the region's differences.

Adebajo and Rashid consider low rate of economic integration and internal differences to still be the defining problems in organization's development despite gradual progress ${ }^{4}$. Thus they state that ECOWAS, being the key regional platform, was largely unable to overcome its major challenges in the economic field or bind the differences of its participants in terms of wealth and development rate. Such assessment goes against the postulates of the neo-Liberalism (viewing peaceful cooperation and equal integration as a universal means of conflict resolution). This fact predetermines a distance between Adebajo and Rashid on the one hand and the Kofi Annan Center representatives on the other.

3 Treaty of the Economic Community of West African States. Lagos, 28 May 1975. URL: http://www.international democracywatch.org/attachments/351_ecowas $\% 20$ treaty $\%$ 20of\%201975.pdf (accessed: 11.11.2018).

4 Over the years of ECOWAS existence the internal trade turnout has grown only insignificantly, in 2010 reaching only $10 \%$ out of total trade turnout of the member states, nevertheless the countries are conducting a coordinated trade policy, specifically aimed at the international organizations and external partners. See: [Uexkull 2012: 416]. 
Nevertheless, Adebajo and Rashid recognize that the emergence of ECOWAS contributed to the establishment of a single subregional cooperation platform. It became one of the major tools for finding solutions to the pressing issues that West Africa faces as well as a mechanism for increased regional independence (primarily Francophone states' independence from France). Further development of subregional institutions, the field of security included, was made possible only because of ECOWAS, the two researchers assert. In this respects the authors are diverging from Western scholars who primarily note the importance of the large international organizations rather than ECOWAS [Adebajo, Rashid 2004: 40].

Difficulties in following the set ECOWAS economic agenda faced by the organization's members in the second half of the 1970s are believed by Adebajo and Rashid to have made the non-economic points of the agenda more important. The question of regional security was prominent among them pushing countries of the region to seek joint response to the threats that West Africa faced. In a period between 1976 and 1981 the organization has accepted protocols establishing the principles of collective security and providing the basis for the set-up of a regional peacekeeping force ${ }^{5}$.

\section{The ECOWAS Role in the Liberian Conflict}

The necessity to act upon these arrangements came in 1989-1990 as a civil conflict in Liberia became a threat to regional security and Liberian president Samuel Doe called for assistance from the states of the region in stabilizing the country [Adeleke 1995: 576]. This was the case because the US refused to play a more active role in defense of Doe due to the ensuing Gulf war and shifted priorities. In this situation the existing West African collective security arrangements proved to be the most reliable

\footnotetext{
5 Protocol on Non-Aggression. Economic Community of West African States. Lagos, 20 April 1978. URL: http://documentation.ecowas.int/download/en/legal_documents/ protocols/Protocol\%20on\%20Non-aggression.pdf (accessed: 10.02.2017); Protocol Relating to Mutual Assistance of Defence. Economic Community of West African States. Freetown, 29 May 1981. URL: http://www.operationspaix.net/ DATA/DOCUMENT/3827 v v Protocole_d_Assistance Mutuelle_en_matiere_de_Defense.pdf (accessed: 10.02.2017).
}

mechanism of summoning external support as similar legal and organizational base for direct military intervention was lacking in other integration platforms that Liberia was part of. His call was negatively regarded by the Francophone states closely connected with France. Meanwhile Nigeria actively spoke out in favor of Doe and a possible intervention [Adeleke 1995: 577]. However other Anglophone countries of the region, Ghana and Sierra Leone, were more inclined towards a political solution to the conflict. But even this required the presence of peacekeepers on the ground with the capacity to provide the guarantees of security, stability of the negotiation process and the execution of the agreement reached. ECOMOG (ECOWAS Monitoring Group) was established [Adeleke 1995: 578].

Adebajo sees this mechanism as a way for Nigeria to maximize its regional influence against the Francophone resistance [Adebajo 2002: 37]. Formally the Nigerian leadership that was behind the composition of ECOMOG emphasized that West African countries should independently solve regional security issues, without external meddling of the former colonial powers, hence increasing the extent of West Africa's weight in the world [Kabia 2011:4 -5]. This was received by the former French colonies only as a means to further bolster its regional domination.

Nigeria had to be cleared of hegemonic ambition suspicions. That is how the two scholars explain why Arnold Quainu, a Ghanaian general was appointed to lead the ECOMOG troops on the ground. Nevertheless, it is underlined that Nigeria provided ECOMOG with $80 \%$ of its troops and $90 \%$ of its funds, loosing roughly 1,000 in that mission [Obi 2009: 121-122].

In the following years the major participants of the Liberian conflict split into multiple factions by ethnicity and specific personal loyalties. Their number swelled to 8 and none of them was able to score a decisive military victory and controlling most of the country's territory. The initial ECOWAS plan to fully disarm all parties in several weeks, establishing a provisional government composed of the neutral civilian public servants and holding presidential elections in 12 months has failed [Obi 2009: 121-122].

Adebajo and Rashid explain this by the fact that warlords were not content with giving up arms and 
not receiving posts in the provisional government and because of it the hostilities endured. Nigerian leadership, playing the key role in ECOMOG, in further talks continued to push for non-participation of the warring parties in the provisional government which stalled the disarmament [Adeleke 1995: 581]. However after a serious internal political crisis of 19931998 and a successive transition of government to the civilians Nigeria no longer was willing to contribute to ECOMOG so actively [Adeleke 1995: 582]. Therefore part of is capabilities that were abandoned fell on Ghana to continue.

The country has traditionally maintained a position of neutrality and impartiality and lacking, in contrast to Nigeria, an explicit political interest in the situation. It was noted that the Ghanaian leadership represented by President Rawlings has shown more pragmatism and departed from warlords' nonparticipation in the provisional government. Nevertheless the talks were again stalled as only 3 fractions were offered posts in the government. But despite all the odds Abuja in 1996 saw the signing of the final agreement between the warring factions.

In 1997 presidential elections took place, won by Charles Taylor, a warlord, and in 1998 ECOMOG forces left the country (however they had to return for a similar operation in 2003 as Taylor's regime experienced a military collapse) [Obi 2009: 124]. Thus the Liberian conflict was formally mediated with the participation of the ECOWAS mission based on the classical understanding of state sovereignty which became the basis for the completion of the peacekeeping mandate.

Nevertheless the two scholars critically note that this did not lead to either the cessation of conflict or prolonged regional stability. Internal tensions led to recommencement of hostilities in 1999 [Obi 2009: 124]. The final premise for the end of the conflict is considered by the two authors to be the decline of the Francophone countries' influence. After the death of Houphouet-Boigny and signs of a growing economic, ethnic and political crisis Ivory Coast took a more neutral stance on the Liberian conflict [Adeleke 1995: 583]. After 1993 the country slowly started to economically realign itself with the US instead of France. In its turn France experienced several severe setbacks in the 1990s, especially in Rwanda where the French peacekeepers were accused of complicity in the genocide [Moncrieff 2012: 7]. As a re- sult France no longer could explicitly support figures politically compromised during the civil war despite the high returns of such cooperation. It is by this fact that the authors explain the change in the conflict dynamic and its completion in 2003 by the Accra accord without an active participation of ECOMOG [Adebajo, Rashid 2004: 16].

The dubious success of the ECOMOG operations in Liberia and Sierra Leone allows Adebajo and Rashid to question the effectiveness of the regional security mechanisms existent at that moment. In their 2004 book they emphasize the necessity of reform for these structures, namely codifying security as a broader notion of conflict prevention and resolution, sustaining a social-economic well-being to eliminate sources of conflict. Apart from that intensified cooperation in the ECOWAS political framework turned out to be necessary in order to properly monitor potential conflicts and find solutions. Elaborating the principles for early-warning reaction to crises like the one in Liberia also proved necessary. It is marked that a new ECOWAS treaty was signed at an early stage of the Liberian conflict, extending the peace and security agenda and broadening the notion of external and internal threats ${ }^{6}$. New threats indicated in the more recent ECOWAS documentation include fragmentation of political power in some West African societies, growing political influence of the non-state armed groups, weak state institutions and lack of public trust [Aning 2004: 534 - 535].

It was also noted that a more detailed analysis of the ECOWAS interventions in Liberia and Sierra Leone was undertaken inside the ECOWAS secretariat in late 1990s with the assistance of NGO's. On December 10th, 1999 Abuja saw the acceptance of a protocol project known as Protocol Relating to the Mechanism for Conflict Prevention, Management, Resolution, Peace-Keeping and Security ${ }^{7}$. According to this document, some responsibilities are transferred

6 Revised Treaty. Economic Community of West African States. Cotonou, 24 July, 1993. URL: http:/www.ecowas.int/ wp-content/uploads/2015/01/Revised-treaty.pdf (accessed: 12.11.2018).

7 Protocol Relating to the Mechanism for Conflict Prevention, Management, Resolution, Peace-Keeping and Security. Economic Community of West African States (ECOWAS). Lome, 10 December, 1999. URL: http://www.zifberlin.org/fileadmin/uploads/analyse/dokumente/ECOWAS Protocol_ConflictPrevention.pdf (accessed: 10.02.2017). 
to the Council of Conflict Resolution and Security which is directly responsible for this set of problems. The Council also selects the respective committee responsible for harmonizing staff appointments and specific measures carried out by ECOWAS. The Council consists of 9 members (heads of state, ministers and ambassadors to Abuja) occupying their positions for 2 years on rotation basis (no rotation took place during the Liberian crisis leading to certain countries monopolizing the peace process). 6 votes out of 9 are enough to make the decision.

The Council gathers once every 3 months on the ministerial level and is constantly active on the ambassadorial level with the aid of the respective committee that provides technical and logistic expertise while also determining the national composition of the ECOWAS peacekeeping units and its commanders. The functioning of the committee might be assisted by other security structures as well. A Council of Experts was also summoned to receive timely information support in reacting to potential and existing conflict situations. This system is supplemented by the monitoring centers on the ground, set to preempt the premises for an outbreak of conflict [Aning 2004: 534-535].

\section{Conclusion}

Having considered all the aforementioned processes, Adebajo and Rashid indicate the ability of the West African regional institutions to adapt to changing conditions and raise their own effectiveness despite the presence of serious problems and challenges with the existing system of collective security. According to their opinion, ECOWAS proved more effective in harsh African conditions of poverty and weak institutions than it could have been expected. Meanwhile the UN peacekeeping capacities in West Africa turned out to be limited to large conflicts only, excluding the intercommunal tensions especially common in the last decade. Thus African scholars now have the foundation for questioning the views of the British school of International Relations regarding the fact that effective value-oriented institutions capable of solving all intergovernmental problems peacefully can only emerge at a high stage of socio-economic and political development.

West African peacekeeping experience, as described by Adebajo and Rashid, is full of controversy, and therefore the authors can hardly be suspected in sharing the neo-Liberal stance regarding their belief that supranational mechanisms and respective values are a universal solution to any problem. But despite that the authors are able to make their own contribution into the understanding of regional integration in one of the most unstable regions of the world against the lack of necessary premises, according to the classic theories. Despite the African scholars' connection to the Western discourse in the field of International Relations analysis, these observations allow us to make a general conclusion that the prospects for the international relations studies on the African continent are quite broad and promising.

\section{References}

Adebajo, A. (2002). Building Peace in West Africa: Liberia, Sierra Leone, and Guinea Bissau. Boulder, London: Lynne Rienner.

Adebajo, A., \& Rashid, I. (Eds). (2004). West Africa's Security Challenges: Building Peace in a Troubled Region. Boulder, London: Lynne Rienner.

Adeleke, A. (1995). The Politics and Diplomacy of Peacekeeping in West Africa: The ECOWAS Operation in Liberia. The Journal of Modern African Studies, 33 (4), 569-593.

Amin, S. (1972). Développement et transformations structurelles. Tiers-Monde, 13 (51), 467—490.

Amin, S. (1968). Le développement du capitalisme en Côte d'Ivoire. In: Poirier, J. Dans l'Économie Ostentatoire. Etudes sur l'Économie du Prestige et du Don. Paris: Editions de Minuit. P. 208-209.

Aning, K. (2004). Investing in Peace and Security in Africa: the Case of ECOWAS. Conflict, Security \& Development, 3 , $533-542$.

Aning, K., \& Salihu, N. (2011). Accountability for Intervention: Negotiating Civilian Protection Dilemmas with Respect to Economic Community of West Africa States and Africa Union Interventions. African Security, IV (2), 81—99.

Boateng, A.D.A., \& Osei-Hwedie, K. (2017). Empowering Others: Motives and Strategies Successful Women Adopt. Review of Social Studies (RoSS), 4 (1), $41-58$.

Bull, H. (1977). The Anarchical Society: a Study of Order in World Politics. London: Macmillan.

Gbagbo, L. (1983). Côte-d'Ivoire: Pour une Alternative Démocrtique. Paris: Harmattan.

Geveling, A.L. (2009). Foreign Capital in the Economy of Tropical African Countries (on the Example of Economic Community of West African States, ECOWAS) [dissertation]. Moscow. 
Ginio, R. (2006). French Colonialism Unmasked: the Vichy Years in French West Africa. Lincoln and London: University of Nebraska Press.

Kabia, J.M. (2011). Regional Approaches to Peacebuilding: the ECOWAS Peace and Security Architecture. Paper presented at the BISA-Africa and International Studies ESRC seminar series: African Agency in International Politics. African Agency in Peace, Conflict and Intervention at the University of Birmingham, 7th April, 2011. URL: https:/www.open.ac.uk/ socialsciences/bisa-africa/files/africanagency-seminar2-kabia.pdf (accessed: 20.01.2019).

Keohane, R.O. \& Nye, J.S. (2001). Power and Interdependence: World Politics in Transition. 3rd edition. New York: Longman.

Koulibaly, M. (2007). Côte d'Ivoire. A French Exception. New African, February, 40-42.

Lugard, F.J.D. (1922). The Dual Mandate in British Tropical Africa. Edinburgh, London: William Blackwood and Sons.

Mensa, K.M. (2014). Progressive Formation of Economic Community of Western Africa Countries (EKOVAS) for the Purpose of Economic Integration. Business in Law, 2, 245-246.

Moncrieff, R. (2012). French Relations with Sub-Saharan Africa under President Sarcozy South. African Institute of International Affairs. Occasional Paper No 107, Johannesburg.

Nkrumah, K. (1967). Neo-Colonialism: The Last Stage of Imperialism. Science and Society, 31 (1), $78-81$.

Obi, C. (2009). Economic Community of West African States on the Ground: Comparing Peacekeeping in Liberia, Sierra Leone, Guinea Bissau, and Côte d'Ivoire. African Security, 2, 119-135.

Sankara, T. (1988). Thomas Sankara Speaks: The Burkina Faso Revolution 1983-87. URL: https://vnn4h672d211.storage. googleapis.com/EgrjHtibl8ngeB4XYj11.pdf (accessed: 10.01.2019).

Sawyer, A. (2004). Violent Conflicts and Governance Challenges in West Africa: the Case of the Mano River Basin Area. The Journal of Modern African Studies, 42, 437-463.

Searing, J.F. (2005). Senegal: Colonial Period: Four Communes: Dakar, Saint-Louis, Gorée, and Rufisque. In: Encyclopedia of African History. Vol. 3. Ed. by K. Shillington. New York, London: Fitzroy Dearborn, p. 1334-1335.

Uexkull, E. (2012). Regional Trade and Employment in ECOWAS. In: Policy Priorities for International Trade and Jobs. Ed. by D. Lippoldt. OECD, 2012. URL: https://www.oecd.org/site/tadicite/50288711.pdf (accessed: 20.01.2019).

Watson, A. (2009). Hedley Bull, States Systems and International Societies. Review of International Studies, 14, $147-153$.

Wauthier, C. (2002). Jacques Foccart et les Mauvais Conseils de Félix Houphouët-Boigny. Les Cahiers du Centre de Recherches Historiques. Archives, 30, 1-3.

Received: 03.03.2019

For citations: Shipilov, A.Yu. (2019). West African International Studies: Approaches to Regional Security. Vestnik RUDN. International Relations, 19 (2), 207-217. DOI: 10.22363/2313-0660-2019-19-2-207-217.

About the author: Shipilov Alexander Yurievich — postgraduate student at the Institute of World History (Russian Academy of Sciences), junior fellow researcher at the Laboratory for the Institutional History of the 20th Century, Institute of World History (Russian Academy of Sciences) (e-mail: alexmo1994@gmail.com).

DOI: $10.22363 / 2313-0660-2019-19-2-207-217$

\title{
Проблематика региональной безопасности в работах западноафриканских исследователей международных отношений
}

\author{
А.Ю. Шипилов \\ Институт всеобщей истории Российской академии наук, \\ Москва, Российская Федерация
}

\begin{abstract}
В настоящей работе освещаются наиболее значимые направления западноафриканской мысли в рамках анализа международных отношений, в том числе в сфере региональной безопасности. Рассматриваются основные школы исследований данной проблематики на основе работ местных экспертов, переосмысливающих основные установки неореалистских, неолиберальных и марксистских подходов. В частности, исследуются различные трактовки роли наднациональных региональных структур в разрешении региональных конфликтов на примере либерийской гражданской войны.

Центральное место занимает анализ работ Адекейе Адебаджо и Исмаила Рашида, ведущих западноафриканских специалистов по региональной безопасности. Отражена их оценка перспектив институтов коллективной безопасности в наиболее бедных и нестабильных регионах мира.
\end{abstract}


Цель работы - определить, насколько оригинальными являются подходы А. Адебаджо и И. Рашида в сравнении с их западными и африканскими коллегами, а также то, насколько анализ гражданских конфликтов в Западной Африке 1990 2000-х гг. повлиял на становление теоретических взглядов этих исследователей и в целом способствовал развитию науки о международных отношениях в Африке.

Исследование опирается на компаративистский и историко-генетический методы, а также на метод кейс-стади. Представлены основные элементы проведенного А. Адебаджо и И. Рашидом анализа успехов и неудач западноафриканской интеграции, а также оценки перспектив силового компонента ЭКОВАС. Проведено сравнение их позиции как с взглядами региональных коллег из иных научных школ, так и с положениями теорий, распространенных на Западе и оказавших на авторов наибольшее влияние.

Ключевые слова: Западная Африка, региональная интеграция, Либерия, международные отношения, коллективная безопасность, английская школа

\section{Библиографический список}

Гевелинг А.Л. Иностранный капитал в экономике стран Тропической Африки (на примере Экономического Сообщества Западноафриканских Государств, ЭКОВАС): дис. ... канд. экон. наук. М., 2009.

Менса К.М. Прогрессивное формирование экономического сообщества стран Западной Африки (ЭКОВАС) с целью экономической интеграции // Бизнес в законе. Экономико-юридический журнал. 2014. № 2. С. $245-246$.

Adebajo A. Building Peace in West Africa: Liberia, Sierra Leone, and Guinea Bissau. Boulder, London: Lynne Rienner, 2002.

Adeleke A. The Politics and Diplomacy of Peacekeeping in West Africa: the ECOWAS Operation in Liberia // The Journal of Modern African Studies. 1995. Vol. 33. No 4. P. 569-593.

Amin S. Développement et Transformations Structurelles // Tiers-Monde. 1972. T. 13. No 51. P. 467-490.

Amin S. Le Développement du Capitalisme en Côte d'Ivoire // Dans l'Économie Ostentatoire. Etudes sur l'Économie du Prestige et du Don. Ed. by J. Poirier. Paris: Editions de Minuit, 1968. P. 208-209.

Aning E.K. Investing in Peace and Security in Africa: the Case of ECOWAS // Conflict, Security \& Development. 2004. No 3. P. 533-542.

Aning K., Salihu N. Accountability for Intervention: Negotiating Civilian Protection Dilemmas with Respect to Economic Community of West Africa States and Africa Union Interventions // African Security. 2011. Vol. IV. No 2. P. 81—99.

Boateng A.D.A., Osei-Hwedie K. Empowering Others: Motives and Strategies Successful Women Adopt // Review of Social Studies (RoSS). 2017. Vol. 4. No 1. P. 41-58.

Bull H. The Anarchical Society: a Study of Order in World Politics. London: Macmillan, 1977.

Gbagbo L. Côte-d'Ivoire: Pour une Alternative Démocrtique. Paris: Harmattan, 1983.

Ginio R. French Colonialism Unmasked: the Vichy Years in French West Africa. Lincoln and London: University of Nebraska Press, 2006.

Kabia J. M. Regional Approaches to Peacebuilding: the ECOWAS Peace and Security Architecture. Paper presented at the BISA-Africa and International Studies ESRC seminar series: African Agency in International Politics. African Agency in Peace, Conflict and Intervention at the University of Birmingham, 7th April, 2011. URL: https://www.open.ac.uk/ socialsciences/bisa-africa/files/africanagency-seminar2-kabia.pdf (accessed: 20.01.2019).

Keohane R.O., Nye J.S. Power and Interdependence: World Politics in Transition. 3rd edition. New York: Longman, 2001. Koulibaly M. Côte d'Ivoire. A French exception // New African. 2007. February. P. 40—42.

Lugard F.J.D. The Dual Mandate in British Tropical Africa. Edinburgh, London: William Blackwood and Sons, 1922.

Moncrieff R. French Relations with Sub-Saharan Africa under President Sarcozy. South African Institute of International Affairs. Occasional Paper No 107. Johannesburg, 2012.

Nkrumah K. Neo-Colonialism: The Last Stage of Imperialism // Science and Society. 1967. Vol. 31. No 1. P. 78 -81.

Obi C. Economic Community of West African States on the Ground: Comparing Peacekeeping in Liberia, Sierra Leone, Guinea Bissau, and Côte d'Ivoire // African Security. 2009. Vol. 2. P. 119-135.

Sankara T. Thomas Sankara Speaks: The Burkina Faso Revolution 1983-87. URL: https://vnn4h672d211.storage. googleapis.com/EgrjHtibl8ngeB4XYj11.pdf (accessed: 10.01.2019).

Sawyer A. Violent Conflicts and Governance Challenges in West Africa: the Case of the Mano River Basin Area // The Journal of Modern African Studies. 2004. Vol. 42. P. 437- 463.

Searing J.F. Senegal: Colonial Period: Four Communes: Dakar, Saint-Louis, Gorée, and Rufisque // Encyclopedia of African History. Vol. 3 / Ed. by K. Shillington. New York, London: Fitzroy Dearborn, 2005. P. 1334-1335.

Uexkull E. Regional Trade and Employment in ECOWAS // Policy Priorities for International Trade and Jobs / Ed. by D. Lippoldt. OECD, 2012. URL: https://www.oecd.org/site/tadicite/50288711.pdf (accessed: 20.01.2019).

Watson A. Hedley Bull, States Systems and International Societies // Review of International Studies. 2009. Vol. 14. P. 147153. 
West Africa's Security Challenges: Building Peace in a Troubled Region / Ed. by A. Adebajo, I. Rashid. Boulder, London: Lynne Rienner, 2004.

Wauthier C. Jacques Foccart et les Mauvais Conseils de Félix Houphouët-Boigny // Les Cahiers du Centre de Recherches Historiques. Archives. 2002. No 30. P. 1 -3.

Дата поступления статьи: 03.03.2019

Для цитирования: Shipilov A.Yu. West African International Studies: Approaches to Regional Security // Вестник Российского университета дружбы народов. Серия: Международные отношения. 2019. T. 19. № 2. С. 207-217. DOI: 10.22363/2313-0660-2019-19-2-207-217.

Сведения об авторе: Шипилов Александр Юрьевич - аспирант Института всеобщей истории РАН, младший научный сотрудник лаборатории «Институциональная история XX века» Института всеобщей истории РАН (е-таil: alexmo1994@gmail.com). 